
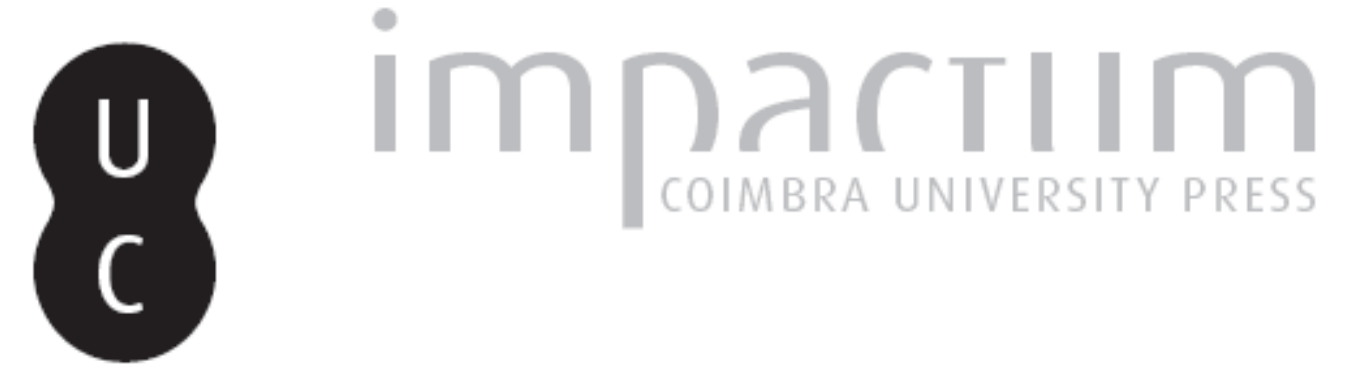

\title{
Castor e Pólux, modelos para Niso e Euríalo na Eneida?
}

Autor(es): $\quad$ Sousa, Francisco Edi de Oliveira

Publicado por: Sociedade Brasileira de Estudos Clássicos

URL persistente:

URI:http://hdl.handle.net/10316.2/35769

DOI:

DOI:http://dx.doi.org/10.14195/2176-6436_22-1_6

Accessed : $\quad$ 26-Apr-2023 12:44:43

A navegação consulta e descarregamento dos títulos inseridos nas Bibliotecas Digitais UC Digitalis, UC Pombalina e UC Impactum, pressupõem a aceitação plena e sem reservas dos Termos e Condições de Uso destas Bibliotecas Digitais, disponíveis em https://digitalis.uc.pt/pt-pt/termos.

Conforme exposto nos referidos Termos e Condições de Uso, o descarregamento de títulos de acesso restrito requer uma licença válida de autorização devendo o utilizador aceder ao(s) documento(s) a partir de um endereço de IP da instituição detentora da supramencionada licença.

Ao utilizador é apenas permitido o descarregamento para uso pessoal, pelo que o emprego do(s) título(s) descarregado(s) para outro fim, designadamente comercial, carece de autorização do respetivo autor ou editor da obra.

Na medida em que todas as obras da UC Digitalis se encontram protegidas pelo Código do Direito de Autor e Direitos Conexos e demais legislação aplicável, toda a cópia, parcial ou total, deste documento, nos casos em que é legalmente admitida, deverá conter ou fazer-se acompanhar por este aviso.

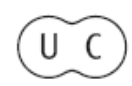




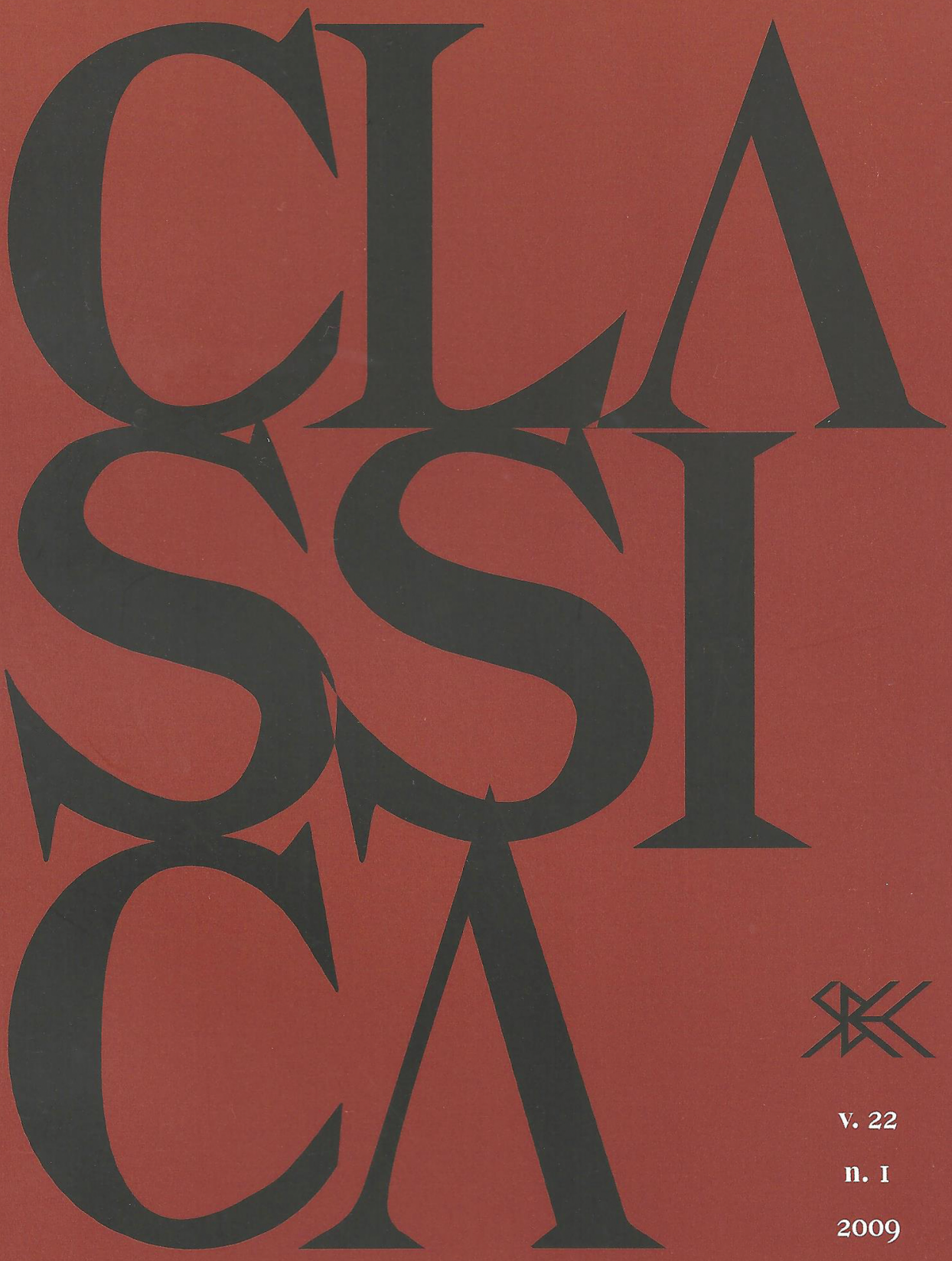




\title{
Castor e Pólux, modelos para Niso e Euríalo na Eneida?
}

\author{
Francisco Edi de Oliveira Sousa \\ Universidade Federal do Ceará \\ Brasil
}

Resumo. O episódio de Niso e Euríalo expõe uma peculiar amicitia entre dois guerreiros, cuja morte provoca forte efeito patético. Seu modelo principal seria a Doloneia; entre os secundários, mencionam-se: o Rhesus, atribuído a Eurípides; a embaixada para Aquiles na Ilíada; a viagem de Telêmaco na Odisseia; relatos da guerra contra Aníbal nos Anais, de Ênio; a relação entre Orestes e Pílades na Ifigênia em Táuris, de Eurípides. Tais modelos, todavia, não propiciam um exame satisfatório da afeição e do fim que os une. Assim, este estudo discute um substrato poético capaz de iluminar a fidelidade e o modus mortis de Niso e Euríalo: o par Castor-Pólux.

Palavras-chave. Eneida; amicitia; fidelidade; Niso-Euríalo; Castor-Pólux.

tantum infelicem nimium dilexit amicum (Verg. Aen. 9.430)

O leitor da Eneida não deixa ileso as páginas que estampam os nomes Niso e Euríalo: impressiona-o a amizade; a morte o comove. No nono canto (168-502), uma façanha lhes cerceia a vida, e a poesia os consagra. Admite-se como modelo primordial dessa passagem a Doloneia (Il. 10), contudo daí não derivam a amicitia e o fim que os arrebatam. Com que textos tais aspectos dialogam? Esta leitura investiga um possível substrato poético capaz de iluminar a fidelidade e o modus mortis de Niso e Euríalo: o par Castor-Pólux.

Apresentam-se de início o contexto e a trama do episódio. Em seguida, faz-se um comentário dos principais modelos reconhecidos. Discute-se, enfim, a hipótese de a fidelidade e o modus mortis de Niso e Euríalo refletirem matizes de Castor e Pólux; para tanto, revisam-se poemas relativos a esse par grego, pertinentes a esta leitura e compostos até a época de Virgílio.

Email: ediletras@hotmail.com 
O nono canto, marcado pela ausência de Eneias, denota uma estrutura tripartida, fundada em dois dias e uma noite: no primeiro dia, Turno ataca o acampamento troiano e tenta atear fogo aos barcos, que se salvam transformando-se em ninfas (1-167); vem a noite com a aventura de Niso e Euríalo, cujo desfecho trágico deslinda-se ao amanhecer (168-502); nesse segundo dia, a trombeta convoca nova batalha, e Turno consegue penetrar no abrigo troiano, de onde escapa jogando-se no rio Tibre (503-818).

No centro desse canto, o episódio de Niso e Euríalo pode ser dividido em quatro partes: três cobrem a façanha e a morte; a quarta, fatos posteriores à morte.

A primeira parte (168-313) comporta os seguintes eventos: os dois guardam uma porta do acampamento (176-83); inquieto, Niso cogita atravessar o campo inimigo, alcançar a cidade de Palanteu e avisar Eneias do perigo que ameaça os troianos, e Euríalo decide acompanhá-lo (184-223); dirigem-se ao conselho dos chefes, o qual delibera sobre a necessidade de se enviar um mensageiro a Eneias (224-8); Niso expõe seu plano (229-45); Aletes louva a iniciativa, e Ascânio enuncia recompensas pelo sucesso da missão (246-80); preocupado com sua mãe, Euríalo pede a Ascânio que a ampare caso pereça (280-302); em seguida, os chefes armam-nos, Ascânio lhes diz as mensagens para Eneias (303-13) - as quais são dissipadas pelas auras e qualificadas como inrita (313), prenúncio do fracasso.

Na segunda parte (314-66), ocorre a façanha. No final de seu morticínio, perto do amanhecer, Euríalo apodera-se de componentes de armadura (fáleras, um boldrié e um elmo); e os dois enfim dão continuidade à missão.

Na terceira parte (367-449), dá-se o desfecho trágico. No caminho de Palanteu, o elmo há pouco posto por Euríalo brilha à luz da lua, e assim são vistos por cavaleiros que regressam da cidade de Latino para o cerco; tentam se ocultar na vegetação; Euríalo se perde e é capturado; Niso, já longe e livre, percebe sua ausência, volta e o encontra cercado por inimigos; arremessa lanças e vitima dois homens; em consequência, Volcente eleva sua espada contra Euríalo, o que força Niso a se revelar e a suplicar pela vida do amigo; não adianta, Volcente o abate; em desespero, brandindo a espada, Niso se lança aos golpes adversários, mata Volcente e cai sobre o corpo de Euríalo. Conclui-se essa peripécia com uma apóstrofe que lhes promete fama através da poesia (446-9).

A quarta parte (450-502) traz o amanhecer, quando as cabeças dos jovens são exibidas, o que desencadeia o pranto da mãe de Euríalo.

Dessas partes, em função do objetivo deste trabalho, apenas as três primeiras são examinadas. As pesquisas dedicadas a essa passagem abordam em geral quatro aspectos: os modelos; a relação entre eles; questões 
sociais, cívicas, filosóficas, religiosas suscitadas pela missão, pelos discursos das personagens; a funcionalidade desses acontecimentos no enredo da Eneida. Ao investigar a possibilidade de Castor e Pólux subjazerem a Niso e Euríalo, esta leitura vincula-se em especial ao primeiro desses aspectos e eventualmente discute os demais. Apresentados o contexto e a trama do episódio, segue um comentário dos modelos reconhecidos.

A primeira seção da Eneida 9 (1-167: o ataque de Turno ao acampamento troiano e a tentativa de atear fogo aos barcos) corresponderia à Ilíada 8, canto em que Heitor decide invadir o acampamento grego e atear fogo aos barcos. O ataque de Heitor é interrompido pela noite (485-6); ele então recomenda a preparação de fogueiras, comidas e vinho para aguardar o amanhecer; e o canto encerra-se com tais preparativos (487-565). Na Eneida, o ataque de Turno também é interrompido pela noite (156-8); ele então recomenda a preparação de fogueiras e vinhos para esperar um novo dia de combate; e a primeira seção encerra-se com tais preparativos (12367). Durante essa noite, acontecem na Ilíada a embaixada para Aquiles (9) e a Doloneia (10); na Eneida, o episódio de Niso e Euríalo. Desses cantos homéricos, examine-se o décimo: no início, Agamêmnon não consegue dormir e espreita as fogueiras e os festejos dos oponentes (1-16); inquieto, procura Nestor (17-24); também sem sono, Menelau vai até o irmão (25-34); os dois decidem convocar o conselho dos chefes para descobrir um meio de salvar os barcos e o exército (35-71); reúnem-se os chefes (72-202); Nestor propõe a expedição de espionagem ao campo rival (203-17); Diomedes se apresenta e escolhe Odisseu como parceiro (218-53); armam-se e lançam-se à expedição sob a proteção de Atena (254-98). No outro lado, Heitor reúne os chefes e propõe uma expedição de espionagem ao campo grego (299312); Dolão se apresenta e requer como recompensa os cavalos e o carro de Aquiles (313-27); Heitor aquiesce, Dolão se arma e parte (328-39); na execução das missões, Dolão é capturado, cede informações e é morto por Diomedes (339-457); Odisseu oferece as armas de Dolão a Atena e pede à deusa que os conduza às tendas onde dormem os trácios chefiados por Reso (458-68); alcançam o local, Diomedes trucida Reso e doze homens enquanto Odisseu rouba os cavalos, depois retornam (469-514); Apolo desperta Hipocoonte, primo de Reso, e os trácios tomam conhecimento do ocorrido (515-25); os espiões gregos chegam ao seu campo, Odisseu relata os feitos, banham-se e libam em honra de Palas Atena (526-79).

Cotejando esse canto com o passo de Niso e Euríalo, observa-se que a situação inicial de Niso evoca a de Agamêmnon: ele se mostra inquieto ao espreitar as fogueiras e os festejos inimigos, concebe seu plano e o expõe ao companheiro (176-96). Como Agamêmnon e Menelau, os jovens discutem 
a questão e em seguida se encaminham ao conselho dos chefes (197-233). A explanação de Niso diante do conselho (234-345) lembra a proposta de Nestor. Parte da recompensa prometida por Ascânio a Niso (o cavalo e as armas de Turno) evoca a recompensa exigida por Dolão. E o ato de vestir as armas e a expedição (303-449) retomam o vestir as armas e a expedição de Diomedes e Odisseu - mas com um resultado bem distinto. A partir desse cotejo, constata-se que o par Niso-Euríalo tem como modelos AgamêmnonMenelau a princípio, depois Diomedes-Odisseu e a desdita de Dolão'.

Eventos da Doloneia são explorados no Rhesus, de Eurípides. Tal peça é considerada por Barbara Pavlock ${ }^{2}$ um segundo modelo maior do episódio de Virgílio e propiciaria, ao lado da Ilíada, um debate sobre gloria e pietas. Quanto à gloria, Pavlock postula ser um objetivo do poeta latino discutir tal noção como um conceito social e analisa seu papel nos dois modelos (p. 208-10): na Ilíada, Diomedes e Odisseu, atendendo a uma solicitação do conselho, subordinariam o desejo de honra e glória à causa comum dos gregos, esperando obtê-las como recompensa social, enquanto Dolão seria motivado pelo desejo de glória pessoal, o que violentaria os padrões de uma sociedade heroica; no Rhesus, haveria uma valorização (um tanto cética) da busca de Dolão por glória material. A Eneida, dialogando com esses modelos, trataria tal noção como um conceito eminentemente social: Pavlock (p. 212) assume que, por um prisma romano, gloria relaciona-se com dever cívico. No episódio, Niso refletiria um desejo de glória pessoal (nam mihi facti / fama sat est, 194-5), enquanto Euríalo seria de início motivado por amor a Niso, posteriormente também pelo desejo de glória pessoal e recompensas materiais (como indicariam os versos 197-8: magno laudum percussus amore / Euryalus). Pavlock (p.216) distingue no verso 354 um reflexo de que a aspiração de glória pessoal provocaria a atitude errada na missão: sensit enim nimia caede atque cupidine ferri. Nenhum deles, pois, repercutiria tal noção como valor social; destarte, a glória via poesia (fiada nos versos 446-9) seria a única possível (p. 224).

Para discutir a pietas, Pavlock (p.218-9) recorre à expressão que apresenta Niso no quinto canto: Nisus amore pio pueri (296) - o sentido de pio nesse contexto desconcerta muitos estudiosos. Aliando a ideia de

\footnotetext{
${ }^{1}$ S. Casali, em um abrangente ensaio (S. CASAli, Nisus and Euryalus: exploiting the contradictions in Virgil's "Doloneia”, HSCPh 102, 319-54, 2004), destaca o fato de a "Doloneia de Virgílio" moldar-se tanto na missão bem-sucedida de Diomedes e Odisseu quanto na fracassada de Dolão; da combinação desses modelos contrastantes adviriam as "contradições" intrínsecas ao episódio.

${ }^{2}$ B. PAvLock, Epic and Tragedy in Vergil's Nisus and Euryalus Episode, TAPhA 115, 207-24, 1985.
} 
pietas decorrente desse adjetivo ao devotamento de Niso a Euríalo tanto na corrida a pé (5.285-361) quanto na missão, Pavlock (p.222) estima que Niso eleve seu sentimento pelo amigo ao nível de uma pietas devida a um membro da família. Assim, ao abandonar a missão de informar Eneias do perigo que ameaça os troianos, Niso negligenciaria seu dever respeitante à pietas cívica e acima dessa colocaria a pietas "familiar" consagrada a Euríalo - o que significaria uma inversão hierárquica.

Essas reflexões de Pavlock são relevantes: a relativa à gloria ilustra um dos temas mais discutidos nessa passagem; a relativa à pietas, menos debatida, abre uma perspectiva que há de ser aproveitada nesta análise.

Além da Doloneia homérica e de sua recriação no Rhesus, outros modelos assomam, como estes elencados por Philip Hardie 3 : a Odisseia 1-4; os Anais, de Ênio; a Ifigênia em Táuris, de Eurípides; e uma reelaboração dessa peça, feita por Pacúvio. Dentre esses, interessam a esta leitura as peças de Eurípides e Pacúvio.

Como a relação de Niso e Euríalo não corresponde à de Diomedes e Odisseu, busca-se um modelo mais pertinente. Nessa empresa, Hardie (p.32) julga que a relação de Orestes e Pílades na Ifigênia em Táuris influa na desses troianos e assim compara um passo da peça com o da Eneida: no texto de Eurípides, Pílades diz que seria vergonhoso não di-

${ }^{3}$ P. Hardie, Virgil Aeneid Book IX, Cambridge, Cambridge University Press, 1994, p. 2934. Para esse autor (p. 29-30), a expedição também retomaria a Ilíada 9 (como a embaixada vai a um herói retirado dos combates, os jovens troianos procuram um herói ausente) e a viagem de Telêmaco à procura do pai, à noite, com os pretendentes embriagados (o encontro com Volcente evocaria a emboscada dos pretendentes no retorno de Telêmaco). Algumas objeções podem ser feitas: no primeiro caso, Eneias não se retira da guerra, ao contrário, executa nesse momento uma missão necessária ao sucesso troiano, a busca de aliados; no segundo, os paralelos são tênues e derivam de uma aplicação (talvez exagerada neste caso) da teoria segundo a qual a Odisseia seria o modelo principal da Eneida - teoria defendida por G.N. KNAUER (Vergil's Aeneid and Homer, GRBS 5, 61-84, 1964), seguida por E.Ch. KopfF (Virgil and the Cyclic Epics, ANRW II.31.2, 919-47, 1981), F. CAIRns ('The Aeneid as Odyssey' in —- Virgil's Augustan Epic, Cambridge, Cambridge University Press, 177-214, 1989). Hardie (p. 30) ainda comenta a possibilidade de Virgílio ter recorrido a um caso da guerra contra Aníbal abordada nos Anais. Tal hipótese origina-se no fato de a expressão somno uinoque soluti (9.189) aludir a um verso de Ênio: Nunc hostes uino domiti somnoque sepulti (fr. 157 in M.S. Moreno, Ennio: fragmentos, Madrid, CSIC, 1999). Soma-se essa alusão a um relato de Tito Lívio (22.50.1-12): após a batalha de Canas, S. Tuditano convenceu soldados salvos em um campo menor a atravessar as desordenadas forças cartaginesas, entediadas pela calma noturna e cansadas por conta de banquetes, e a se reunir a soldados romanos que estavam em um campo maior. Dando crédito à presença nos Anais do episódio de Niso e Euríalo, Hardie (p. 30) imagina que os versos 446-49 poderiam ter um modelo na epopeia de Ênio. Infelizmente, nem o fragmento dos Anais nem o relato de Tito Lívio desvelam elos mais relevantes a esta leitura. 
vidir a morte com Orestes, e este tenta dissuadi-lo alegando que aquele deveria permanecer a fim de erigir-lhe um túmulo caso morresse e que não poderia abandonar Electra (674-722); no de Virgílio, Euríalo insiste em dividir a façanha com Niso, e este pede que aquele não se arrisque, fique e sepulte seu corpo caso pereça, assegurando que não deseja causar dor à mãe do amigo (197-221). Esse par grego de fato figura como modelo provável para o diálogo destacado por Hardie e assim para contornos da amicitia de Niso e Euríalo. Todavia, diferentemente de Euríalo, Pílades se deixa convencer e aceita retornar sozinho - embora funcional no enredo, tal atitude (revestida de um temor da opinião negativa do povo a seu respeito por ter abandonado o outro) afigura-se estranha para quem Orestes estima o melhor dos amigos, um companheiro de infortúnios (708-10). Após a de Eurípides, Hardie (p. 32) menciona uma tragédia de Pacúvio (provavelmente Dulorestes) em que Orestes e Pílades dizem a uma só voz: ambo ergo una necarier / precamur ${ }^{4}$ (fr. 166 Warmington $^{5}$ ). Desse modo, o texto de Pacúvio daria nova dimensão à amicitia desses dois e reforçaria em solo romano o impacto de sua relação.

Essa proposta de Hardie traz à baila outro par entrevisto nessa passagem da Eneida: Aquiles-Pátroclo. Estudando a questão, John F. Makowski ${ }^{6}$ defende a hipótese de Virgílio ter seguido um ideal de amor descrito por Platão no Banquete para moldar a relação de seus ousados rapazes, caracte-

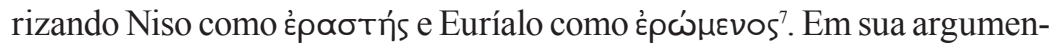
tação (p. 6), quase todos os atos e palavras de Niso seriam motivados por amor a Euríalo - seu nome, inclusive, particípio passado de nitor, refletiria sua devoção amorosa. A ação de Euríalo, por sua vez (p. 12), seria motivada por emulação e desejo de impressionar o amante. Sob esse prisma, o final dos dois deveria ser reputado feliz: assim como Aquiles e Pátroclo são julgados felizes no Banquete porque partilham um épos que lhes pro-

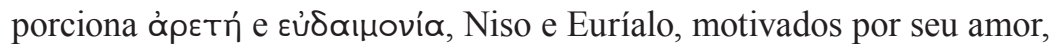

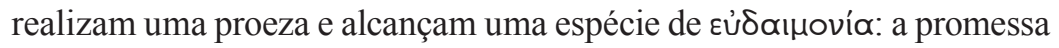
de imortalidade através de versos. Com essa visão, Makowski (p. 15) justifica a frase: Fortunati ambo! (446).

\footnotetext{
${ }^{4}$ Cícero informa que essa cena sempre arrancava aplausos da plateia (Amic. 24) e a cita novamente no Fin. 2.79 e 5.63.

${ }^{5}$ E.H. Warmington, Remains of Old Latin 2, Cambridge (Massachusetts), Harvard University Press, 1936, Loeb.

${ }^{6}$ J.F. Mакоwsкi, Nisus and Euryalus: a platonic relationship, CJ, 85, 1-15, 1989.

${ }^{7}$ Trata-se essencialmente do discurso de Fedro (178b-180b); aliás, nesse trecho se faz referência a uma expedição de amantes e amados e se apregoa ser belo dar a vida por quem se ama. Hardie (p. 32-3) também perfilha essa ideia de Makowski.
} 
Embora Makowski talvez se exceda ao condicionar quase todos os atos e palavras desses jovens ao sentimento que os une, seu estudo evidencia a presença de Aquiles e Pátroclo nessa urdidura. Outra interpretação, porém, pode ser feita desse diálogo com o Banquete: emitindo seu discurso sobre o Amor, a Eneida, de um lado, como constata Makowski, reitera todo o empenho de um guerreiro-amante por seu companheiro, o que em tese robustece uma expedição com tais homens; de outro, expõe o risco maior de um guerreiro-amante colocar o pessoal acima do coletivo.

A relação entre esses troianos decerto reproduz aspectos da desses pares gregos, mas persistem lacunas, em especial quanto ao modus mortis. Verifica-se agora a hipótese de o par Castor-Pólux também constituir um modelo para a fidelidade e sobretudo para o modus mortis de Niso e Euríalo. Tal processo principia com uma revisão (em ordem cronológica e até a época de Virgílio) de textos que abordam Castor e Pólux de maneira propícia a esta análise.

Esse par é citado já na Ilíada: Helena reúne-se a Príamo e a outros chefes que se encontram em uma torre de Troia observando os combates e lhes identifica guerreiros gregos; nesse momento, lamenta a ausência dos irmãos, os quais, sem que ela saiba, estão enterrados na Lacedemônia (3.23644). Helena caracteriza Castor como domador de cavalos (iт то́ $\delta \propto \mu o v$, 237) e Pólux como ớ yáóv (237) e pugilista (238).

No que tange à Odisseia, a partilha da imortalidade é referida quando a alma de Leda se aproxima de Odisseu (11.298-304): Castor e Pólux são designados como corajosos filhos de Tíndaro, aos quais Zeus outorgou o direito de passarem um dia com os mortos, outro com os vivos - o verso 300 é idêntico ao 237 da Ilíada 3, e o 301 é uma variante do 243 da Ilíada

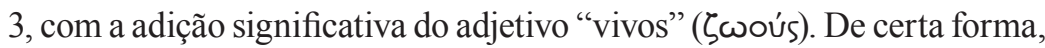
a Odisseia retoma o relato da Ilíada e acrescenta uma filiação e a partilha da imortalidade concedida por Zeus.

Essa distinção entre as epopeias gera um questionamento, condicionado ao fato de esse trecho da Odisseia ser original: a partilha da imortalidade integraria a lenda dos irmãos na época da composição da Ilíada ou se desenvolveu entre essa época e a da composição da Odisseia? Em nota ao verso 238 da Ilíada 3 (que conta Castor e Pólux serem filhos da mesma mãe, sem referência ao pai), e apoiando-se nos versos 243 e 244 (que os declaram enterrados na Lacedemônia), Paul Mazon ${ }^{8}$ afirma que esse poema ignora a partilha da imortalidade. Não é possível assegurar a veracidade dessa afirmação; todavia, o fato de a Ilíada não explorar a "morte" e essa

${ }^{8}$ P. Mazon in Homère, Iliade 1, Paris, Belles Lettres, 1949, p. 78, n. 1. 
partilha abre uma lacuna que há de ser preenchida por um épico posterior, os Cantos Cíprios.

Dois outros textos atados ao nome de Homero tratam de Castor e Pólux: os hinos aos Dióscuros (17 e 33). O primeiro informa a concepção (fecundada por Zeus, Leda deu-os à luz no Taígeto) e os denomina "montadores de rápidos cavalos". O segundo repete a concepção e essa denominação e traz outros dados: Castor recebe o epíteto de "domador de cavalos", Pólux o de "irrepreensível"; o principal atributo deles é socorrer homens em perigo na terra e notadamente no mar, por isso os marinheiros costumam invocá-los e oferecer-lhes cordeiros brancos.

Nenhum desses textos homéricos descreve a relação ou a "morte" de Castor e Pólux; apesar disso, seu exame é relevante, porquanto não apenas possibilita uma visão abrangente e progressiva do trato literário a eles concedido, mas também revela aspectos úteis a esta leitura, sobretudo porque um desses textos, a Ilíada, como dito há pouco, parece valioso para a elaboração de episódios vivenciados por esse par num épico do ciclo troiano, os Cantos Cíprios (Kúmpıa).

Atribuído ao cipriota Estasino", os Cantos Cíprios têm sua datação situada por grande parte dos estudiosos na primeira metade do século VII a.C. ${ }^{10}$. Supostamente dividido em onze livros, seu enredo comportava fatos da guerra de Troia anteriores aos da Ilíada. Eis um sumário em que se destacam os episódios envolvendo Castor e Pólux.

No início, Zeus decide com Têmis um plano para causar a guerra de Troia, cujos instrumentos serão Helena e Aquiles. Pondo o plano em prática, persegue Nêmesis e gera Helena, que é adotada por Leda; em seguida, obriga Tétis a casar-se com Peleu e pede a Hermes que barre a entrada de Éris no casamento, para que ela plante a discórdia entre os convivas; na cerimônia, brota a disputa entre Atena, Hera e Afrodite quanto à beleza; Hermes as conduz ao monte Ida, onde Alexandre faz o julgamento. Ante o juiz, propõem recompensas: Hera, reinados; Atena, vitórias em guerras; Afrodite, o amor de Helena. Afrodite vence e instrui os troianos a cons-

${ }^{9} \mathrm{Na}$ Antiguidade, pensou-se que os Cantos Cíprios também seriam de Homero (cf. Herod. 2.116-17).

${ }^{10}$ Nessa linha, F. JuAn (Euripide et les Légendes des Chants Cypriens: des origines de la guerre de Troie à l'Iliade, Paris, Belles Lettres, 1966, p.24-7 e n. 3 da p.27) a posiciona entre 680 e 660 a.C. Já M.L. West (Greek Epic Fragments, Cambridge, Massachusetts: Harvard University Press, 2003, [Loeb], p. 13), reconhecendo nos fragmentos do poema traços de uma língua mais recente do que a dos homéricos, considera difícil sua composição anteceder à segunda metade do século VI a.C.. 
truir uma frota. Zarpam, aportam na Lacedemônia, onde são recebidos por Castor e Pólux; depois, em Esparta, onde são acolhidos por Menelau, que precisa ir a Creta em meio à visita. Afrodite une Helena e Alexandre, que fogem com parte do tesouro do palácio e se casam em Ílion. Por essa altura, Castor e Pólux são apanhados roubando gado de Idas e Linceu ${ }^{11}$. Este sobe no monte Taígeto para ver ao longe; avista Castor escondido na cavidade de um carvalho e avisa Idas, que mata Castor. Vingando o irmão, Pólux mata Idas e Linceu, e Zeus concede a Castor e Pólux a imortalidade em dias alternados. Íris revela o fato a Menelau, que planeja com Agamêmnon uma expedição contra Ílion. Menelau visita Nestor, e ambos correm a Hélade em busca de aliados. Para fugir à expedição, Odisseu finge insanidade; Palamedes, porém, o desmascara. Os gregos partem de Áulis e chegam à Mísia, que saqueiam supondo ser Ílion; Télefo arma seus mísios e os ataca, mas é ferido pela lança de Aquiles. Vencidos os mísios, os gregos voltam ao mar; e uma tempestade os dispersa; Aquiles acaba em Ciros e se casa com Deidâmia. Quanto a Télefo, seu ferimento não sara; Apolo lhe diz que só Aquiles pode curá-lo; assim, vai a Argos e pede a cura ao herói, prometendo ensinar o caminho de Ílion; Aquiles o cura com a crosta de sua lança, e Télefo cumpre a promessa. Preparando-se a frota em Áulis, Agamêmnon mata um cervo e zomba de Ártemis. Zangada, a deusa impede a frota de zarpar. Calcante explica o mau tempo e a necessidade de sacrificar Ifigênia. No momento da imolação, Ártemis substitui a virgem por um cervo, leva-a para Táuris e a imortaliza. Zarpam, alcançam Tênedos; Tenes reage e é morto por Aquiles. Controlada a situação, os gregos fazem um banquete, durante o qual Filoctetes é picado por uma serpente; sendo o ferimento incurável e pestilento, é abandonado em Lemnos. Chegam a Ílion. Protesilau desembarca e é morto por Heitor. Aquiles desembarca e liquida Cicno. Os troianos recuam; os gregos sitiam-nos e enviam uma embaixada solicitando Helena e o tesouro. Os troianos recusam. Os gregos saqueiam cidades próximas. Aquiles deseja ver Helena e é atendido por Afrodite e Tétis; mais tarde, rouba o gado de Eneias, pilha cidades vizinhas, incluindo Pédaso, de onde traz Briseide, e ainda mata Troilo. Na partilha do butim, Aquiles recebe Briseide; Agamêmnon, Criseida. Uma fome então castiga os gregos; Palamedes aconselha Agamêmnon a buscar as filhas de Ânio para alimentá-los. Assim é feito. Nesse período, em uma pescaria, Palamedes é afogado por Odisseu, auxiliado por Diomedes.

${ }^{11}$ Idas e Linceu são filhos de Afareu, irmão de Tíndaro; portanto, são primos de Castor e Pólux. 
Nessa epopeia, enfim emerge um relato da "morte" de Castor e Pólux, com a concessão da imortalidade por Zeus. Além disso, se a ordem dos acontecimentos estiver correta, chama atenção o fato de os eventos envolvendo os irmãos entremearem-se com a expedição de Alexandre e o "rapto" de Helena. Qual a função desses eventos nesse enredo? É difícil responder; uma hipótese, porém, é possível lançar: uma vez que os poemas do ciclo troiano fundaram-se em grande parte em prefigurações e lacunas existentes nos homéricos, a participação desse par nos Cantos Cíprios fundamentar-se-ia na referida passagem da Ilíada 3 e teria como uma de suas funções (talvez a principal) justificar sua ausência em Troia, lamentada por Helena.

A reconstituição dos Cantos Cíprios desvela uma versão para a "morte", mas ainda não se dispõe de contornos da relação existente entre esses irmãos. O texto com a mais antiga descrição original conhecida dessa "morte" também destaca o laço que os une: o décimo poema das Nemeias de Píndaro. Na primeira parte da ode (1-18), canta-se a cidade de Argos, os feitos de seus filhos e a beleza de suas mulheres: Perseu, Épafo, Hipermnestro, Diomedes, Anfiarau, Alcmena, Dânae, o pai de Adrasto, Tálao ${ }^{12}$ (filho de Bias), Anfitrião e Hércules. Na segunda (19-36) e na terceira (37-54), faz-se o elogio do atleta destinatário do poema, Theaios. Ao fim da terceira (49-54), irrompem Castor e Pólux, membros de uma família de bons atletas, aqueles que presidem os jogos, patronos de Esparta, protetores dos justos; e os irmãos são por fim qualificados com a expressão mıotòv Yévos (54), que os coroa com a virtude da fidelidade (TíotI5). Na quarta parte (55-72), narra-se a vida deles após a "morte" (um dia no Olimpo, outro no Hades) e a luta que lhes sela o destino: Idas e Linceu vingam o roubo de seu gado perpetrado por Castor e Pólux; com sua visão privilegiada, Linceu espreita do alto do Taígeto e descobre Castor escondido no tronco de um carvalho; avisa Idas, que fere Castor com uma lança; Pólux chega e persegue Idas e Linceu, que param perto do túmulo de Afareu, daí retiram uma pedra e atiram-na contra o peito de Pólux, mas não o aniquilam; Pólux então arremessa sua lança e mata Linceu, enquanto Zeus fulmina Idas; os dois corpos jazem na solidão; finda-se essa passagem com a advertência de ser perigoso aos mortais desafiar seres mais poderosos. Na quinta parte (73-90), segue o relato: Pólux corre para Castor e o encontra ainda com vida; chorando, dirige a Zeus seu sofrimento; no final de seu discurso, pede ao deus a morte,

${ }^{12}$ De acordo com PausÂnias (2.21.2), Linceu e Tálao possuíam sepulcros lado a lado na ágora de Argos. 
pois não há glória possível para quem perde um caro amigo, e ressalta o companheirismo de Castor asseverando haver poucos homens fiéis nos momentos difíceis (aqui mais uma vez surge o termo mıotós (78), um realce da virtude caracterizadora desse par); Zeus afirma que Pólux é seu filho; já Castor, Tíndaro o concebeu depois; com isso, Pólux deveria escolher entre seu destino natural, evitando a morte e a velhice no Olimpo, ou partilhar um destino com o irmão, vivendo a metade da vida no Olimpo, a outra sob a terra; sem hesitar, Pólux escolhe partilhar um destino com Castor, que é reanimado.

Essa narrativa de Píndaro é bastante próxima da que integrava os Cantos Cíprios. Diante disso, cabe a pergunta: essa epopeia também exaltaria a fidelidade dos irmãos? Provavelmente sim. De qualquer forma, esse poema das Nemeias não apenas reforça a versão da "morte" de Castor e do ato de Pólux expressa nos Cantos Cíprios, mas ainda delineia com traços contundentes a relação entre eles.

No século III a.C., Teócrito retrabalha a querela entre Castor e Pólux e os filhos de Afareu, mas adota uma causa e um desfecho distintos dos explorados pelo autor dos Cantos Cíprios e por Píndaro. No poema 22, após o anúncio dos atributos dos Dióscuros (1-26), salvadores de homens, cavalos e navios em situação de grande perigo (conteúdo semelhante ao dos hinos homéricos), narram-se duas aventuras: a primeira protagonizada por Pólux (27-134); a segunda, por Castor (135-211). A primeira acontece durante a expedição dos argonautas: ao chegarem à terra dos bébrices, os heróis descem da nave Argo e preparam um acampamento; Castor e Pólux, explorando a região, chegam à morada de Âmico, um gigante contra quem Pólux é obrigado a lutar, sob os olhares dos bébrices e dos tripulantes da Argo; hábil no pugilato, Pólux vence. A segunda aventura traz à tona o rapto das leucípides: eles raptam as filhas de Leucipo e são perseguidos por Idas e Linceu, aos quais elas estavam prometidas; ao chegarem ao túmulo de Afareu, enfrentam-se; Linceu toma a palavra e critica a ação dos Dióscuros; Castor responde e propõe um duelo com Linceu - ao vencedor a noiva; Castor mata Linceu; ao tentar vingar o irmão com uma pedra retirada do túmulo de Afareu, Idas é fulminado por Zeus. Ao fim das aventuras e de uma consideração a respeito do poder dos tindáridas e de Zeus (212-13), a conclusão (214-23) exalta um caminho de mão dupla: de um lado, as grandes façanhas dos heróis oferecem assunto e renome aos poetas; de outro, os cantos dos poetas oferecem glória aos heróis.

Nesse idílio, a narrativa da querela entre Castor e Pólux e os filhos de Afareu apresenta três diferenças em relação às versões anteriormente comentadas: em primeiro lugar, a querela ocorre em razão do rapto das 
leucípides $^{13}$ (não por gado); em segundo lugar, nesse confronto, Castor tem mais relevo (enquanto Pólux sobressai nos Cantos Cíprios e no poema de Píndaro); enfim, aqui apenas os filhos de Afareu morrem.

São esses os textos compostos até a época de Virgílio que abordam esses irmãos de forma mais substanciosa. A esta leitura são mais pertinentes os que salientam a relação entre eles e os eventos da morte de Castor e da partilha da imortalidade.

A discussão de um possível diálogo entre o episódio de Niso e Euríalo e esses textos principia com um argumento histórico: a presença desse par grego no universo romano é atestada ao menos desde princípios do século V a.C.. Relatando a batalha do lago Regilo (c. 496 a.C.), Tito Lívio (2.19-20) informa que Aulo Postúmio, enfrentando dificuldades ante uma coalizão de latinos e homens vinculados aos tarquínios, invocou Castor, prometendo erguer-lhe um templo em caso de vitória. Os romanos venceram, e a promessa foi paga em 15 de julho de 484 a.C., quando um templo foi consagrado a Castor, o domador de cavalos (Liv. 2.42.5). Cícero (Nat. D. 2.6) também alude à "participação" de Castor e Pólux nessa batalha e relata uma versão lendária segundo a qual eles teriam guiado a cavalo o exército romano para a vitória ${ }^{14}$.

Uma vez que se sabe que esses irmãos faziam parte do universo romano, que não representariam entidades estranhas ao receptor da Eneida, examina-se como subjazeriam ao episódio de Niso e Euríalo.

Nessa epopeia, há uma alusão explícita: si fratrem Pollux alterna morte redemit / itque reditque uiam totiens $(6.121-22)^{15}$. O texto destaca

${ }^{13}$ Talvez os Cantos Cíprios também contivessem o conflito causado pelo rapto das leucípides, mas sem que fosse o fatal: Pausânias (3.16.1), comentando um santuário de Hilaíra e Febe, indica a existência delas nessa epopeia ao informar que seu autor as julgava filhas de Apolo. Na Biblioteca (3.11.2), Apolodoro relata os dois conflitos: primeiramente o rapto das noivas; depois o roubo do gado, sendo o segundo a razão da luta mortal entre os primos. ${ }^{14}$ Confira ainda o relato de Dionísio de Halicarnasso (Ant. Rom. 6.13). Desde cedo, o culto a Castor em Roma liga-se à cavalaria: em 15 de julho, havia uma corrida de cavalos (transuectio equitum) cujo rito principiava com um sacrifício no templo de Castor presidido pelos tribuni celerum.

${ }^{15}$ Algumas edições apendem ao fim da fábula 80 de Higino uma consideração a respeito de um "ditado" ("alterna morte redemptus») e de um rito romano (cum desultorem mittunt, unus duos equos habet, pileum in capite, de equo in equum transilit, quod ille sua et fratris uice fungatur), supostamente inspirados na atitude de Pólux; esse ditado evocaria a alusão feita aos irmãos na Eneida. Nessa fábula, Higino trabalha a querela fatal entre Castor e Pólux e os filhos de Afareu adotando o rapto das leucípides como motivo: Febe (sacerdotisa de Minerva) e Hilaíra (sacerdotisa de Diana), prometidas a Idas e Linceu, são raptadas por Castor e Pólux; Idas e Linceu tentam recuperá-las; em combate, Castor mata Linceu; abalado, Idas esquece o conflito e se dedica ao sepultamento do irmão; Castor surge, proíbe a 
justamente a atitude redentora de Pólux ante a morte de Castor. Tal alusão ocorre em um momento especial do poema, um ponto estruturante que prefigura a segunda metade: no sexto canto, consultada por Eneias, a Sibila discerne guerras terríveis (86), outro Símois (88), outro Xanto (88), outro acampamento dórico (88), outro Aquiles (89), outra esposa estrangeira como causa de males (93-4). Tais palavras vaticinam uma reedição da "guerra de Troia" no Lácio. Na resposta de Eneias a esse vaticínio, dá-se a alusão aos irmãos, usada como argumento (ao lado dos nomes de Orfeu, Teseu e Alcides) para que o herói possa realizar uma descida aos infernos com o fito de ver o pai.

Desvela-se um "recomeço da guerra de Troia" com a chegada ao Lácio, a promessa de união com Lavínia e a oposição de Turno. Efetuada nesse contexto, a alusão a Castor e Pólux é muito expressiva. No ciclo troiano, o poema que narra o princípio dessa guerra são os Cantos Cíprios; cotejando-se o enredo desse épico com a segunda metade da Eneida, notam-se eloquentes pontos de contato: a chegada ao Lácio, o envio de uma embaixada ao rei Latino, o conflito iniciado por causa de uma mulher e a busca de aliados empreendida por Eneias (e a visita a Evandro evoca a de Menelau a Nestor). Portanto, nessa reedição da guerra de Troia, a Eneida recupera os primórdios da contenda e recria assuntos dos Cantos Cíprios. Quanto à participação de Castor e Pólux nesse "primeiro" poema do ciclo troiano, os dois episódios com eles aconteceriam nas imediações desses assuntos recriados na Eneida: circundariam o rapto de Helena e seu casamento com Páris e viriam logo antes da viagem de Menelau (ou mesmo durante essa viagem) em busca de conselhos e aliados. Reunindo-se esses elementos, quando se soma o fato de a alusão explícita aos irmãos transparecer no instante em que se anuncia um recomeço da guerra de Troia ao fato de a aventura de Niso e Euríalo ocorrer em um contexto de recriação de matérias dos Cantos Cíprios e, mais precisamente, em um contexto correspondente à suposta posição dos episódios de Castor e Pólux nessa epopeia, obtém-se um resultado que, no mínimo, legitima o exame da subjacência do par grego ao par latino. Tal subjacência, no entanto, não se configura (como a Doloneia) um modelo estrutural para o passo da

construção da sepultura e vitupera o falecido; Idas então mata Castor; avisado, Pólux acorre, mata Idas e sepulta Castor; Pólux pede a Júpiter, seu pai, o direito de partilhar seu destino com Castor, filho de Tíndaro; a súplica é atendida; viriam então o ditado e o rito. À parte sua originalidade, essa consideração final insinua que a relação entre os irmãos, caracterizada pelo ato redentor de Pólux, teria deixado marcas expressivas no mundo romano. Na fábula 251, cuja temática é o retorno dos infernos, Higino mais uma vez resgata essa passagem da Eneida (Castor et Pollux Iovis et Ledae filii alterna morte redeunt). 
Eneida: pressupõe-se que a amicitia e o modus mortis de Niso e Euríalo dialoguem com a virtude característica dos irmãos e com a tessitura da morte de Castor e do ato redentor de Pólux. Esse diálogo se deixa ouvir com mais nitidez quando se cotejam alguns poemas comentados e o episódio de Niso e Euríalo.

Infelizmente, na reconstituição dos Cantos Cíprios (conforme o sumário apresentado), não há detalhes dos sentimentos envolvendo a morte de Castor; tais detalhes, como se viu, eclodem no décimo poema das Nemeias de Píndaro. Um cotejo desse texto com o episódio de Niso e Euríalo explicita aproximações reveladoras: a virtude que caracteriza o par da Eneida é a mesma que une o par dessa ode (e provavelmente o dos Cantos Cíprios), a míotıs (tal virtude corresponderia em princípio à fides romana); a afirmação de Pólux de não haver glória possível àquele que perde um ente querido justificaria a decisão de Niso de, já livre dos inimigos, abandonar sua missão e voltar para salvar Euríalo; Pólux provoca a morte de quem atentou contra a vida de Castor e depois pede sua própria "morte", e Niso mata aquele que tirou a vida de Euríalo e assim encontra sua própria morte. Além dessas incisivas aproximações, constata-se que os dois pares alcançam a imortalidade em decorrência de sua virtude maior. Como narra Píndaro, Pólux compartilha o destino de Castor, desprezando sua vida e a glória de ser um deus sozinho; com isso, estende sua imortalidade ao irmão. Niso, por sua vez, por fidelidade a Euríalo, abdica de sua própria vida e da grande glória social que lhe caberia caso cumprisse sua missão; com isso, alcança para os dois uma imortalidade concedida não por Júpiter, mas pela poesia (Aen. 9.446-9). Destarte, como vozes do Rhesus podem ser ouvidas no diálogo com a Doloneia, vozes dos Cantos Cíprios ouvem-se nesse diálogo com a ode de Píndaro.

No que tange à apóstrofe ${ }^{16}$, como se disse, Hardie imagina que Virgílio possa tê-la imitado dos Anais. Um paralelo um pouco mais palpável pode ser feito entre ela e a conclusão do poema de Teócrito (214-23): o poeta invoca os filhos de Leda e lhes pede $\mathrm{k} \lambda$ Éos (214) para sua poesia; depois afirma que os aedos são amigos dos que participaram da destruição de Ílion e que um aedo de Quios ${ }^{17}$ lhes assegurou glória ao celebrar a

${ }^{16}$ N.M. Horsfall (A Companion to the Study of Virgil, Leiden, Brill, ${ }^{2} 2000$ [Brill's Scholars' List], p. 172), com uma leitura um tanto biográfica, considera esses versos um

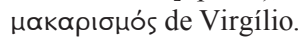

${ }^{17}$ Seria Homero o aedo de Quios? A princípio, as referências à cidade de Príamo, aos barcos aqueus, às batalhas de Ílion e a Aquiles parecem designar a Ilíada; todavia, nesse poema Castor e Pólux não são celebrados. O poema do ciclo troiano que de fato os celebra são os Cantos Cíprios, texto que também aceitaria tais referências; além disso, na Antiguidade, 
cidade de Príamo, os barcos aqueus, as batalhas de Ílion e Aquiles; ao fim, oferece-lhes os doces dons das Musas, seu canto, o mais belo presente que se pode ofertar aos deuses. Configura-se o referido caminho de mão dupla: os feitos dos heróis fornecem cantos e renome aos poetas; esses cantos, glória aos heróis. Nesse poema, os Dióscuros sobrevivem, e não ocorre a cessão da imortalidade por Zeus; em contrapartida, essa reflexão final de certa forma substitui a imortalidade divina por uma advinda da poesia. A Eneida parece ter recuperado tal aspecto, pois essa reflexão se materializa exatamente na conclusão da proeza de Niso e Euríalo: o feito deles outorga renome ao poema, ao poeta, cujos versos inscrevem os dois na memória do Tempo (si quid mea carmina possunt, / nulla dies umquam memori uos eximet aeuo, Eneida 9.446-7).

Os cotejos empreendidos entre a Eneida, os Cantos Cíprios, o poema de Píndaro e o de Teócrito já concretizam a subjacência do par CastorPólux ao par Niso-Euríalo. E dois índices alusivos reforçam essa subjacência. O primeiro, o termo "Euríalo", amplia o vínculo entre os pares. Nas Argonáuticas de Apolônio de Rodes, quando Pólux se apresenta para lutar contra Âmico, Castor e Tálao ajudam-no a se preparar para o combate (2.62-4); esse Tálao é pai de Adrasto, referido por Píndaro (Nem. 10.12), e avô de Euríalo, o pugilista vencido por Epeio nos jogos em honra de Pátroclo (Il. 23.677-99). Diante disso, o nome "Euríalo" vincula o par da Eneida ao Castor-Pólux via Argonáuticas. O segundo índice intensifica o diálogo com os Cantos Cíprios: o verso 226 (ductores Teucrum primi, delecta iunentus), que anuncia o conselho dos chefes troianos, alude ao 1.86 do De Rerum Natura (ductores Danaum delecti, prima uirorum), que anuncia o conselho dos chefes gregos para o sacrifício de Ifigênia - um exemplo de crimes cometidos em nome da religião. $\mathrm{O}$ fato de tal evento pertencer ao enredo dos Cantos Cíprios substancia a presença dessa epopeia nesse passo da Eneida ${ }^{18}$.

Após todos esses delineamentos, cabe um arremate dos paralelos formados entre as personagens: as analogias seriam Niso-Pólux e Euríalo-Castor. Niso e Pólux são os que se sacrificam pelo companheiro,

circulava a hipótese de Homero ser o autor dessa epopeia. Seria, portanto, mais provável pensar que Teócrito se refira aqui aos Cantos Cíprios, julgando seu autor ser Homero - ou aos Cantos Cíprios e à Ilíada, julgando serem ambos de Homero.

${ }^{18}$ Essa alusão também forja um paralelo entre o episódio de Niso e Euríalo e o sacrifício de Ifigênia. Casali daí depreende a ideia de que "Nisus and Euryalus can be viewed as victims sacrificed on the altar of an ideology at the service of the leaders" (p.340). Esse fecundo paralelo não é aqui discutido por fugir ao escopo do trabalho; aborda-o outra pesquisa em curso sobre a relação entre o ciclo troiano e a Eneida. 
os autores do ato redentor, motivados pela fidelidade. Euríalo e Castor são os que "perecem" e levam seus companheiros a partilhar a "morte" com eles; além disso, vinculam-se por intermédio do cavalo: Euríalo ganha um cavalo como prêmio na corrida (Aen. 5.286-361); Castor é constantemente denominado "domador de cavalos". E esse arremate complementa-se com a concretização do seguinte sentido: as ações de Castor e Pólux são contestáveis (e o poema de Teócrito as recrimina com rigor), mas são redimidos e imortalizados pela virtude que os une e que se evidencia em Pólux na hora da perda; do mesmo modo a ação de Niso e Euríalo é contestável, mas são redimidos e glorificados graças à virtude que os une e que se evidencia em Niso na hora da perda.

Embora o diálogo entre esses pares esteja patente, alguém poderia contestá-lo alegando diferenças de laços: Niso e Euríalo são amigos; Castor e Pólux, irmãos. Contra essa objeção, retome-se de início o estudo de Pavlock a respeito da noção de pietas: ela defende a hipótese de o devotamento que une Niso e Euríalo elevar-se à dimensão de uma pietas familiar. George Duckworth ${ }^{19}$ também reconhece marcas de uma pietas familiar no amor de Niso por Euríalo: a disposição de Niso para salvar o amigo prefiguraria a de Lauso para salvar seu pai (10.796-9). Talvez nessa linha de raciocínio resida o sentido maior da expressão amore pio (5.296): recheado de fides e de amor, o sentimento de Niso pelo amigo erguer-se-ia ainda às raias de uma pietas familiar. Corrobora essa ideia o paralelo estabelecido na primeira parte do episódio entre Niso-Euríalo e Agamêmnon-Menelau - paralelo, aliás, não explorado nos estudos desta matéria. Logo, é possível entrever na relação de Niso e Euríalo elementos que sabem a laços fraternos; e eles assim se aproximam ainda mais de Castor e Pólux ${ }^{20}$.

Ao fim desta leitura, cabe apenas reiterar que um eloquente diálogo com textos que abordam Castor e Pólux descortina um substrato poético capaz de iluminar a fidelidade e o modus mortis de Niso e Euríalo. E a luz se lança de forma especial na direção do ato redentor, da virtude que mostra sua face inteira no momento da perda do irmão, do amigo e os

${ }^{19}$ G.E. Duckworth, The Significance of Nisus and Euryalus for Aeneid IX-XII, AJPh 88, 129-50, 1967, p. 148.

${ }^{20} \mathrm{O}$ episódio faz duas evocações a Rômulo e Remo, mas aparentemente sem ligação com Castor e Pólux; com efeito, os contextos sugerem reflexões sobre guerras fratricidas no Lácio. A primeira eclode entre as vítimas de Niso, com Ramneto (324-9), termo que evoca "Rômulo" (cf. CASALI, p. 346 e n. 46-8) e Remo (330). A segunda caracteriza Euríalo como Remo: as palavras ditas por Volcente ao matar Euríalo (422-3) reverberam as de uma advertência feita por Rômulo provavelmente a Remo nos Anais (fr. 47 MoRENo), de Ênio. 
imortaliza pela graça de Zeus, pela graça da poesia - fato exaltado pela Eneida no verso si fratrem Pollux alterna morte redemit (6.121).

Com a manifesta presença de Castor e Pólux no cenário em que atuam Niso e Euríalo, amplia-se o horizonte de significação deste episódio, deste poema, e afloram novas perspectivas de investigação.

TitLE. Castor and Pollux, models for Nisus and Euryalus in the Aeneid?

ABstract. The episode of Nisus and Euryalus shows a peculiar amicitia between two warriors, whose death causes a strong pathetic effect. Its main model would be the Doloneia; among the secondary, there are the Rhesus attributed to Euripides, the embassy to Achilles in the Iliad, the journey of Telemachus in the Odyssey, reports of the war against Hannibal in the Annals of Ennius, the Orestes and Pylades relationship in Euripides' Iphigenia in Tauris. Nevertheless, those models do not provide an appropriate analysis of the affection and the end that bind them. On that account, this study discusses a poetic substrate which is capable of enlightening the fidelity and the modus mortis of Nisus and Euryalus: the pair Castor-Pollux.

KeYwords. Aeneid; amicitia; fidelity; Nisus-Euryalus; Castor-Pollux. 